\title{
Destructive craniovertebral junction tuberculosis and antituberculosis treatment
}

Cyriac Abby Philips, MD, DM, and T.K. Jayarajan, DNB, MRCS, FIPM

Neurology ${ }^{\circledR}$ 2018;91:668-669. doi:10.1212/WNL.0000000000006292

Correspondence

Dr. Philips

abbyphilips@gmail.com

Figure Sagittal T2-weighted MRI of the craniovertebral junction

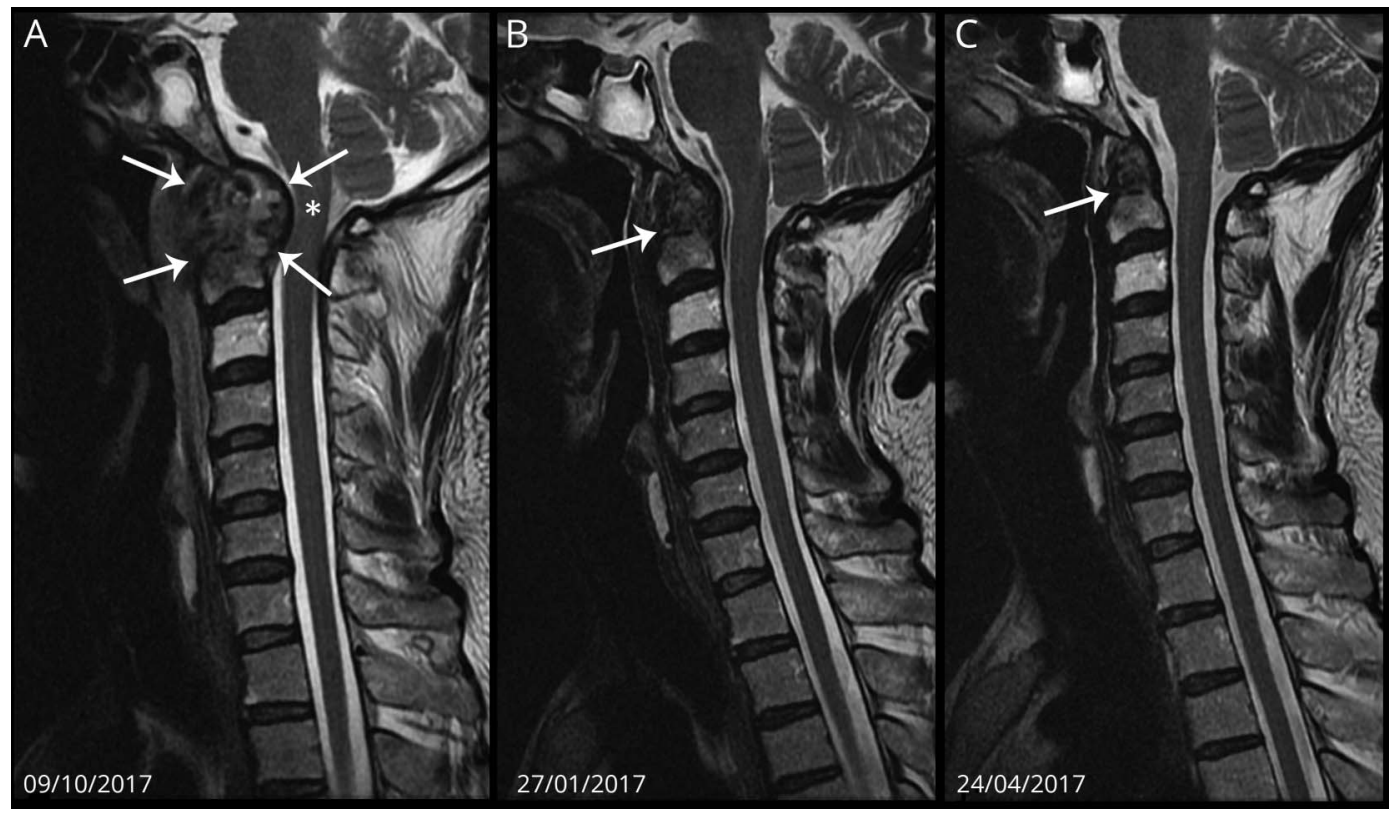

(A) Sagittal T2-weighted MRI of the craniovertebral junction shows destructive cortical bone changes with periodontal heterogeneous fluid collection causing significant compression of the spinal cord. On antituberculosis therapy, the size of the collection and associated bone and marrow changes are reduced (B) after 3 months; after 6 months, there is complete resolution of disease (C).

A 42-year-old man with cirrhosis had destructive craniovertebral junction tuberculosis on MRI. There was bone destruction involving the odontoid process, axis vertebra, and heterogeneous fluid collection (figure, A, arrows) compressing the spinal cord (figure, A, asterisk). Antituberculosis therapy (ATT) was initiated and follow-up scans (figure, B and C, arrows) showed complete resolution. Craniovertebral junction tuberculosis is extremely rare but lifethreatening, occurring in $0.3 \%-1 \%$ of tuberculous spondylitis cases. ${ }^{1}$ Almost all patients with neurologic deficits require early surgical intervention. ${ }^{2}$ In high-risk surgical patients, awaiting ATT response to prevent surgery-related morbidity and mortality is worthwhile.

\section{Author contributions}

Dr. Philips: study concept, final approval. T.K. Jayarajan: image acquisition, final approval.

\section{Acknowledgment}

The authors thank Dr. S. Rajesh for formatting the images.

\section{Study funding}

No targeted funding reported.

From The Liver Unit, Cochin Gastroenterology Group (C.A.P.), and Neurosurgery (T.K.J.), Ernakulam Medical Centre, Kochi, Kerala, India.

Go to Neurology.org/N for full disclosures. Funding information and disclosures deemed relevant by the authors, if any, are provided at the end of the article. 


\section{Disclosure}

The authors report no disclosures relevant to the manuscript. Go to Neurology.org/N for full disclosures.

\section{References}

1. Goel A. Tuberculosis of craniovertebral junction: role of facets in pathogenesis and treatment. J Craniovertebr Junction Spine 2016;7:129-130.

2. Qureshi MA, Afzal W, Khalique AB, Pasha IF, Aebi M. Tuberculosis of the craniovertebral junction. Eur Spine J 2013;22:612-617.

\section{Add Your Voice! Apply for 2019 Neurology on the Hill}

The AAN continues to fight for common sense health care reform that promotes neurology and protects your patients. Add your voice to the conversation at Neurology on the Hill from February 25 to 26, 2019, and help educate members of Congress so we can address critical health policy problems together. If selected, you will receive training to bring you up-to-date on key issues. Then, you will go to Capitol Hill for face-to-face meetings with congressional members and their staffs.

Learn more and apply by November 2, 2018, at AAN.com/view/NOH.

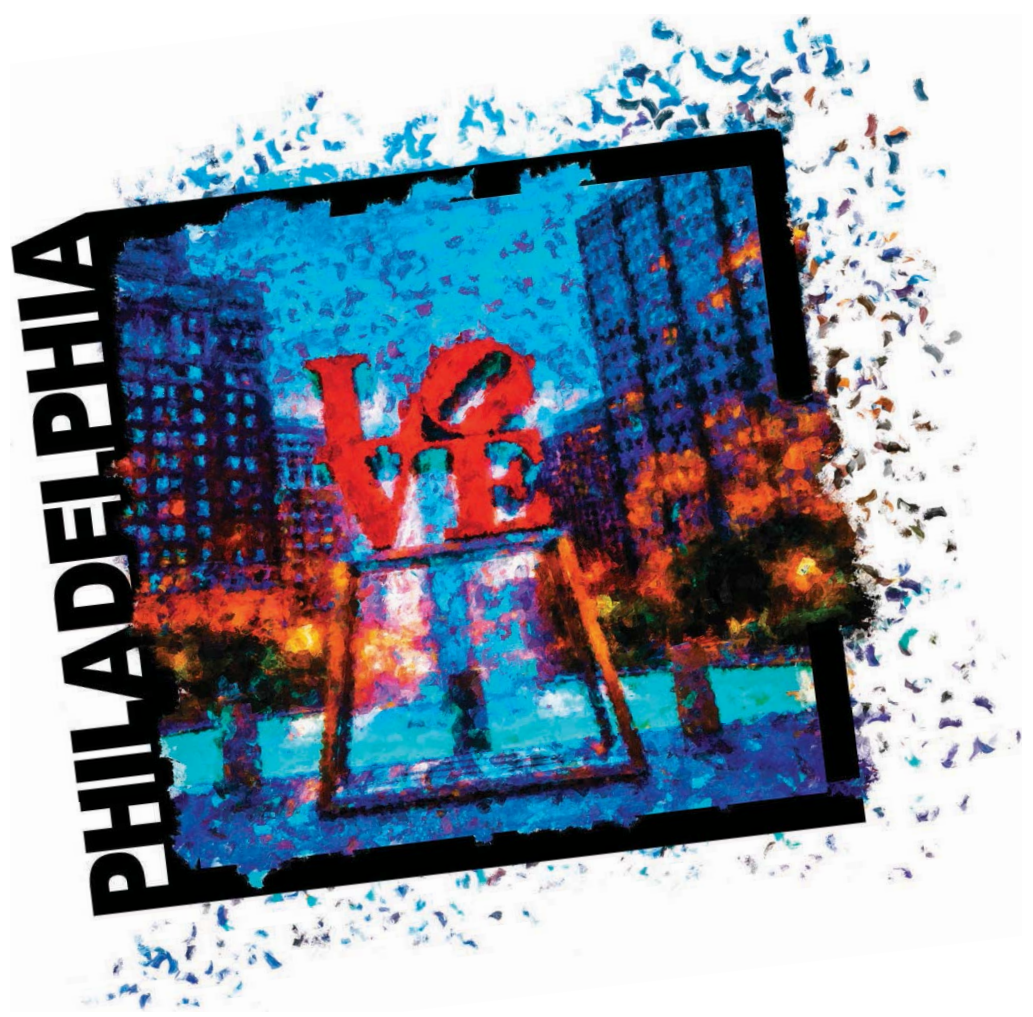

\section{IMPORTANT DATES AND DEADLINES}

Don't miss these important dates for the 2019 AAN Annual Meeting, set for May 4-10, 2019, in Philadelphia.

Learn more at AAN.com/view/AM19

- Abstract Submission Deadline: October 22, 2018

- Awards Application Deadline: October 24, 2018 


\title{
Neurology
}

\author{
Destructive craniovertebral junction tuberculosis and antituberculosis treatment \\ Cyriac Abby Philips and T.K. Jayarajan \\ Neurology 2018;91;668-669 \\ DOI 10.1212/WNL.0000000000006292
}

This information is current as of October 1, 2018

\section{Updated Information \& Services}

References

Subspecialty Collections

Permissions \& Licensing

Reprints including high resolution figures, can be found at: http://n.neurology.org/content/91/14/668.full

This article cites 2 articles, 0 of which you can access for free at: http://n.neurology.org/content/91/14/668.full\#ref-list-1

This article, along with others on similar topics, appears in the following collection(s):

All Clinical Neurology

http://n.neurology.org/cgi/collection/all_clinical_neurology All Spinal Cord

http://n.neurology.org/cgi/collection/all_spinal_cord

Bacterial infections

http://n.neurology.org/cgi/collection/bacterial_infections

Critical care

http://n.neurology.org/cgi/collection/critical_care

MRI

http://n.neurology.org/cgi/collection/mri

Information about reproducing this article in parts (figures,tables) or in its entirety can be found online at:

http://www.neurology.org/about/about_the_journal\#permissions

Information about ordering reprints can be found online:

http://n.neurology.org/subscribers/advertise

Neurology ${ }^{\circledR}$ is the official journal of the American Academy of Neurology. Published continuously since 1951, it is now a weekly with 48 issues per year. Copyright (O) 2018 American Academy of Neurology. All rights reserved. Print ISSN: 0028-3878. Online ISSN: 1526-632X.

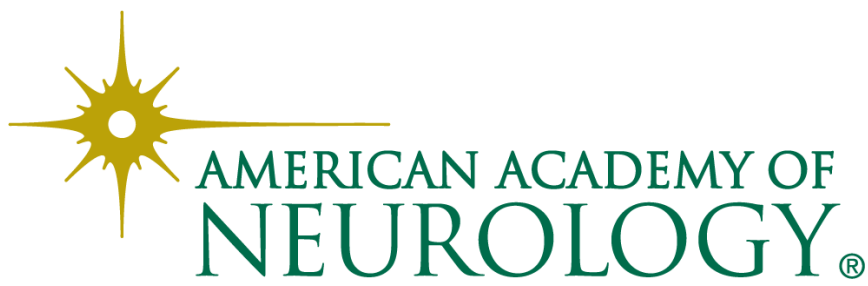

